\title{
PERANCANGAN IKLAN LAYANAN MASYARAKAT PENTINGNYA MENCUCI TANGAN MENGGUNAKAN SABUN
}

\author{
Muhammad Sabri' ${ }^{1}$, Yollanda Finky ${ }^{2}$ \\ Prodi Desain Komunikasi Visual \\ Fakultas Seni dan Desain \\ Universitas Potensi Utama Medan \\ shabry92@gmail.com¹,yolanda.finky@gmail.com²
}

\begin{abstract}
ABSTRAK
Mencuci tangan bermanfaat agar tangan menjadi bersih dan dapat membunuh kuman yang ada di tangan, dan terbukti secara ilmiah dapat mencegah penyakit menular seperti diare, Infeksi Saluran pernafasan Atas (ISPA) dan flu burung. Walaupun demikian pentingnya perilaku cuci tangan pakai sabun (CTPS) untuk mencegah penyakit - penyakit menular masih belum di pahami masyarakat secara luas dan praktiknya masih belum banyak diterapkan dalam kehidupan sehari-hari. (patria asda, 2020), Oleh sebab itu diperlukan sebuah media komunikasi untuk mengingatkan kembali kepedulian masyarakat tentang mencuci tangan, media komunikasi yang digunakan dalam iklan layanan masyarakat ini adalah berupa poster, bertujuan untuk menyampaikan pesan kepada khalayak tentang kepedulian pentingnya mencuci tangan sebelum melakukan aktivitas atau sesudah melakukan aktivitas menggunakan sabun, sehingga masyakat lebih sehat dengan membudayakan cuci tangan pakai sabun.
\end{abstract}

Kata kunci : cuci tangan, iklan layanan masyarakat, poster.

\begin{abstract}
Washing hands is useful so that hands are clean and can kill germs on the hands, and it is scientifically proven to prevent infectious diseases such as diarrhea, upper respiratory infections (ARI) and bird flu. However, the importance of washing hands with soap (CTPS) to prevent infectious diseases is still not widely understood by the community and its practice is still not widely applied in everyday life. (patria asda, 2020), therefore a communication medium is needed to remind the public about washing hands, the communication media used in this public service advertisement is a poster, which aims to convey a message to the public about the importance of washing hands before carrying out activities. or after doing activities using soap, so that the community is healthier by making a culture of washing hands with soap.
\end{abstract}

Keywords : hand washing, posters, public service announcements.

\section{PENDAHULUAN}

Kebersihan dan kesehatan merupakan salah satu aspek penting dalam kehidupan. Salah satu cara menjaganya adalah mencuci tangan dengan baik dan benar. Akan tetapi, kurangnya kesadaran masyarakat akan hal itu membuat pola hidup mereka tidak sehat dan berkembang menjadi bibit penyakit. 
Tangan adalah salah satu penghantar utama masuknya kuman penyakit ke tubuh manusia. Mencuci tangan adalah kegiatan membersihkan bagian telapak, punggung tangan, jari dan kuku jari. Tujuannya agar bersih dari kotoran dan membunuh kuman penyebab penyakit dapat yang merugikan kesehatan.

Cuci tangan dengan sabun dapat menghambat masuknya kuman penyakit ke tubuh manusia melalui perantaraan tangan. Kuman penyakit seperti virus dan bakteri tidak dapat terlihat secara kasat mata sehingga sering diabaikan dan mudah masuk ke tubuh manusia.

Hampir semua orang mengerti pentingnya cuci tangan menggunakan sabun, namun tidak membiasakan diri untuk melakukannya dengan benar pada saat yang penting. Mencuci tangan pakai sabun dilakukan pada 5 waktu penting: sebelum makan, sesudah buang air besar, sebelum memegang bayi, sesudah menceboki anak, dan sebelum menyiapkan makanan. Jika hal ini dilakukan akan dapat mengurangi hingga 47\% angka kesakitan karena diare dan 30\% infeksi saluran pernafasan akut atau ISPA (infeksi saluran pernapasan atas).

\section{STUDI LITERATUR}

Cuci tangan adalah proses membuang kotoran dan debu secara mekanis dari kulit kedua belah tangan dengan memakai sabun dan air. Tujuannya adalah untuk menghilangkan kotoran dan debu secara mekanis dari permukaan kulit dan mengurangi jumlah mikroorganisme sementara (Dahlan dan Umrah, 2013).

Cuci tangan merupakan salah satu cara untuk menghindari penyakit yang ditularkan melalui makanan. Kebiasaan mencuci tangan secara teratur perlu dilatih pada anak. Jika sudah terbiasa mencuci tangan sehabis bermain atau ketika akan makan ,aka diharapkan kebiasaan tersebut akan terbawa sampai tua (Samsuridjal, 2009).

Menurut redaksi halosehat. 2021, waktu yang Diperlukan untuk Mencuci Tangan

1. Sebelum dan sesudah makan

2. Sebelum dan sesudah menyiapkan bahan makanan

3. Sebelum dan sesudah mengganti popok

4. Setelah buang air besar dan buang air kecil

5. Setelah bersin atau batuk 
6. Sebelum dan setelah menggunakan lensa kontak

7. Setelah menyentuh binatang

8. Setelah menyentuh sampah

9. Sebelum menangani luka

10. Setelah memegang benda "umum"

Bahaya Penyakit Akibat Tidak mencuci Tangan, Berikut ini jenis penyakit yang mungkin timbul ketika anda melewatkan cuci tangan :

1. Sakit perut

2. Muntaber

3. Flu

4. Radang tenggorkan

5. Amandel

6. Asma

7. Gangguan pernapasan lain

Selain itu masih banyak sekali penyakit yang dapat timbul karena kuman yang masuk ke tubuh. Selain itu, kuman tersebut juga dapat masuk ke dalam tubuh melalui sela-sela kuku jari. Banyak sekali penyakit yang disebabkan oleh kontaminasi kuman pada bagian tangan. (redaksi halosehat. 2021)

Iklan layanan masyarakat (ILM) adalah iklan yang menyajikan pesan-pesan sosial yang bertujuan untuk membangkitkan kepedulian masyarakat terhadap sejumlah masalah yang harus mereka hadapi, yakni kondisi yang bisa mengancam keselarasan dan kehidupan umum.

(https://id.wikipedia.org/wiki/Iklan_layanan_masyarakat di akses tanggal 25 februari 2021)

\section{PEMBAHASAN}

\section{a. Konsep Kreatif}

Untuk Iklan layanan masyarakat pentingnya mencuci tangan menggunakan sabun ini, ada tiga ide besar yang akan dijadikan sebagai pijakan dalam perancangannya. Ide tersebut adalah sebagi berikut: 
1. Tangan

2. Sabun

3. Air

Ketiga ide besar diatas akan diwujudkan ke dalam bentuk visual yang menarik agar bisa menarik perhatian masyarakat, dan diaplikasikan ke dalam dalam sebuah desain poster dan media pendukung lainnya.

\section{b. Alternatif Sketsa}
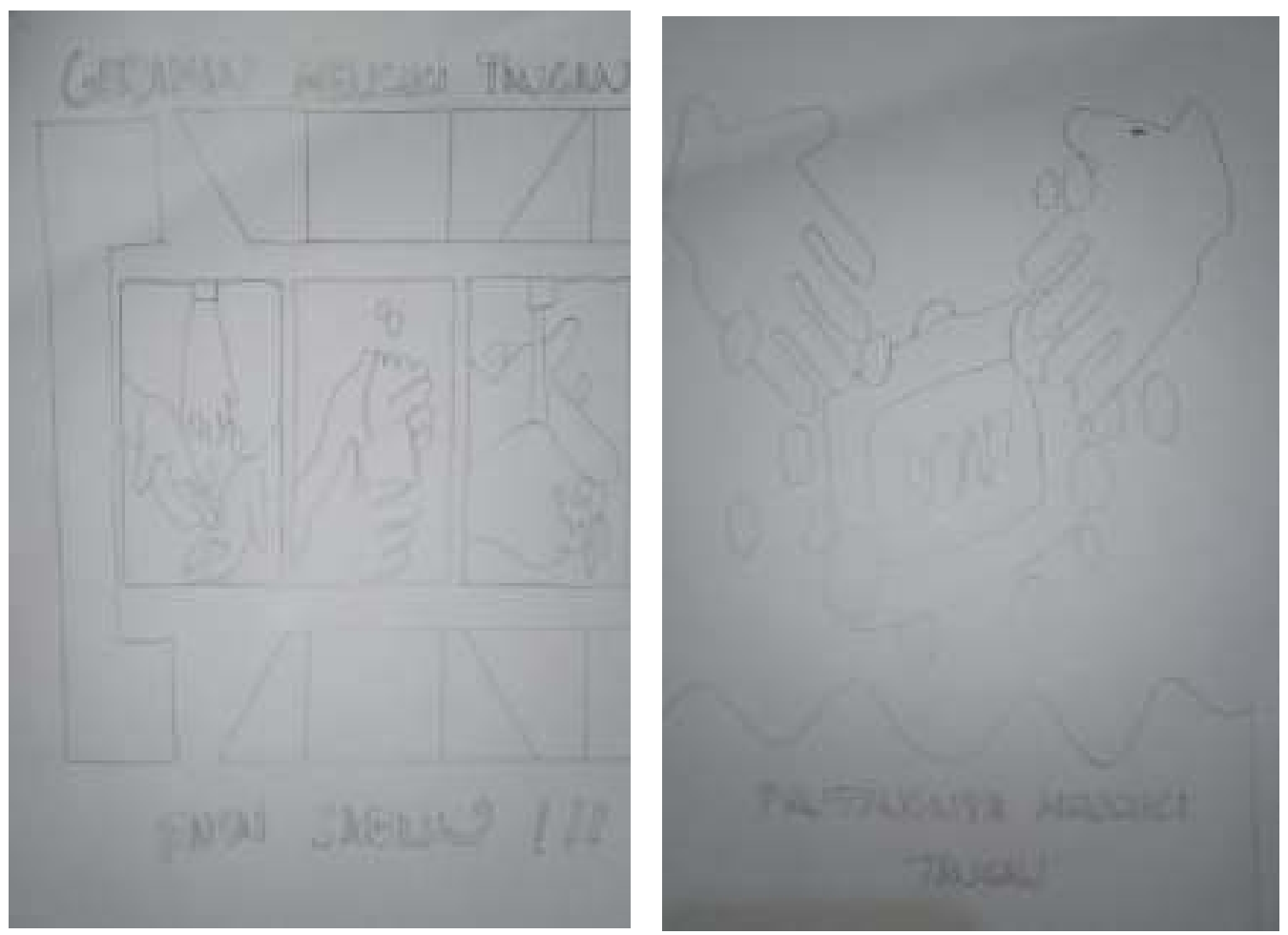

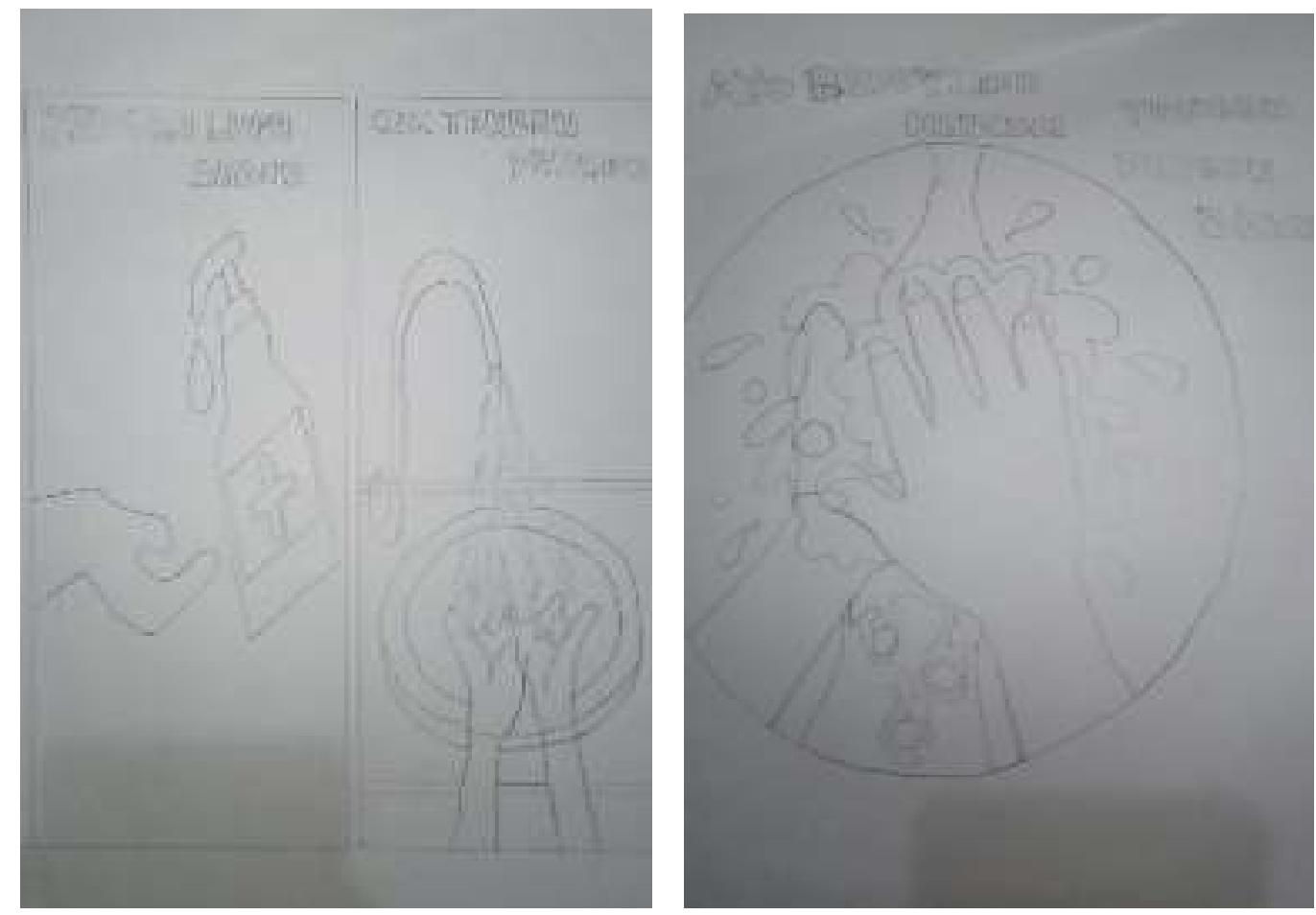

Gambar 1. Alternatif Sketsa

\section{c. Desain digital}

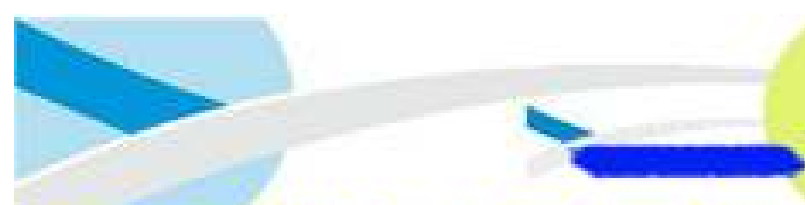

Jangen tupa Cuci Tangan

sabun

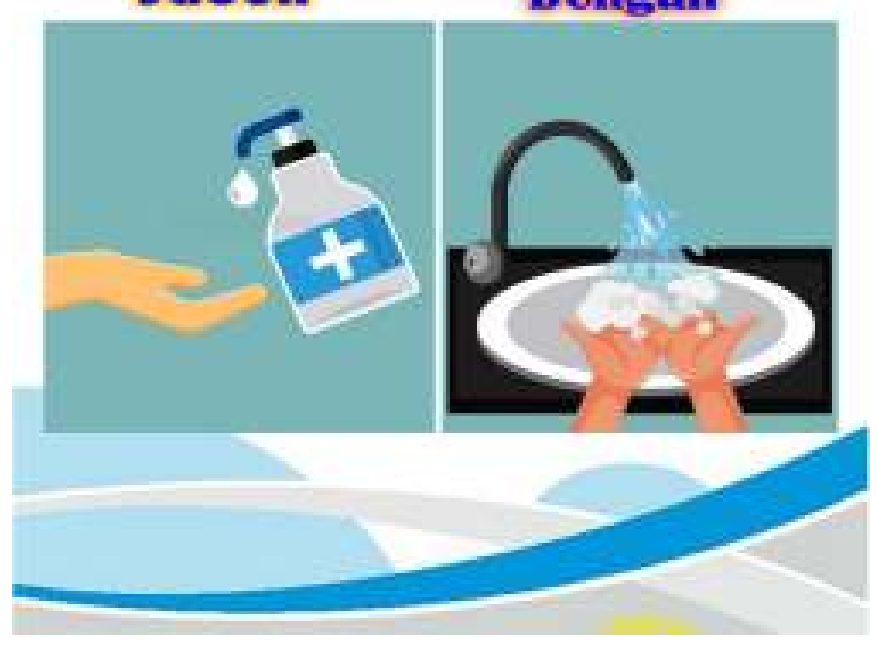

Desain poster - 1 


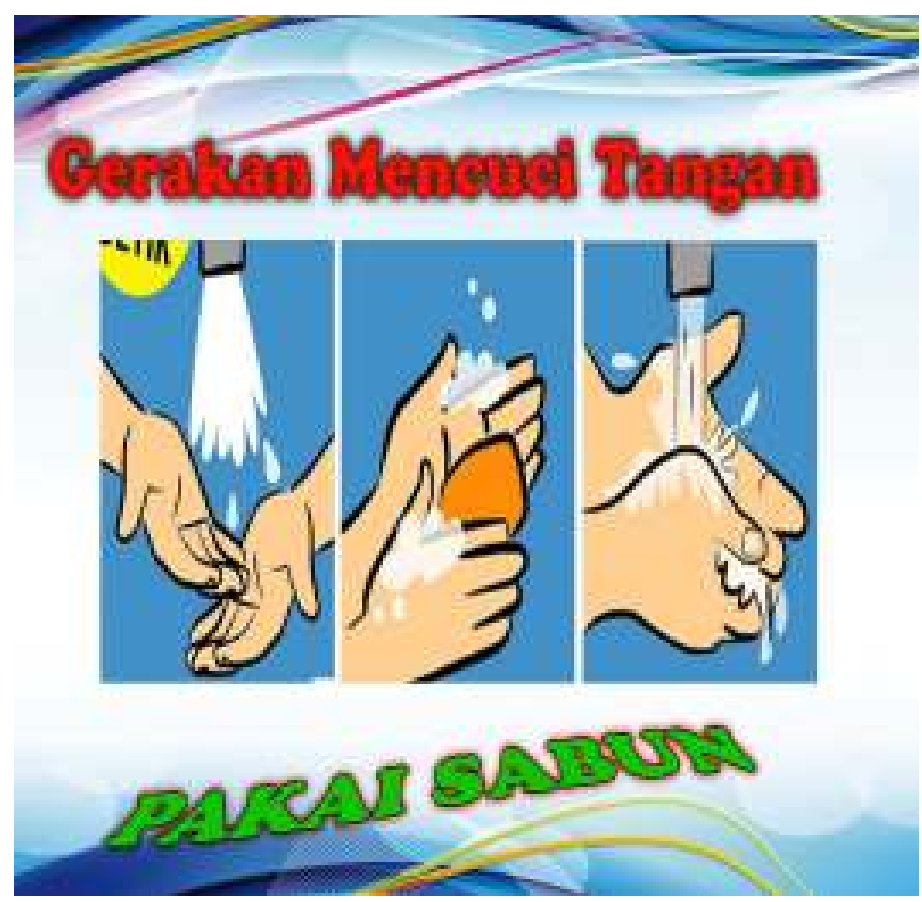

Gambar 2. Desain poster - 2

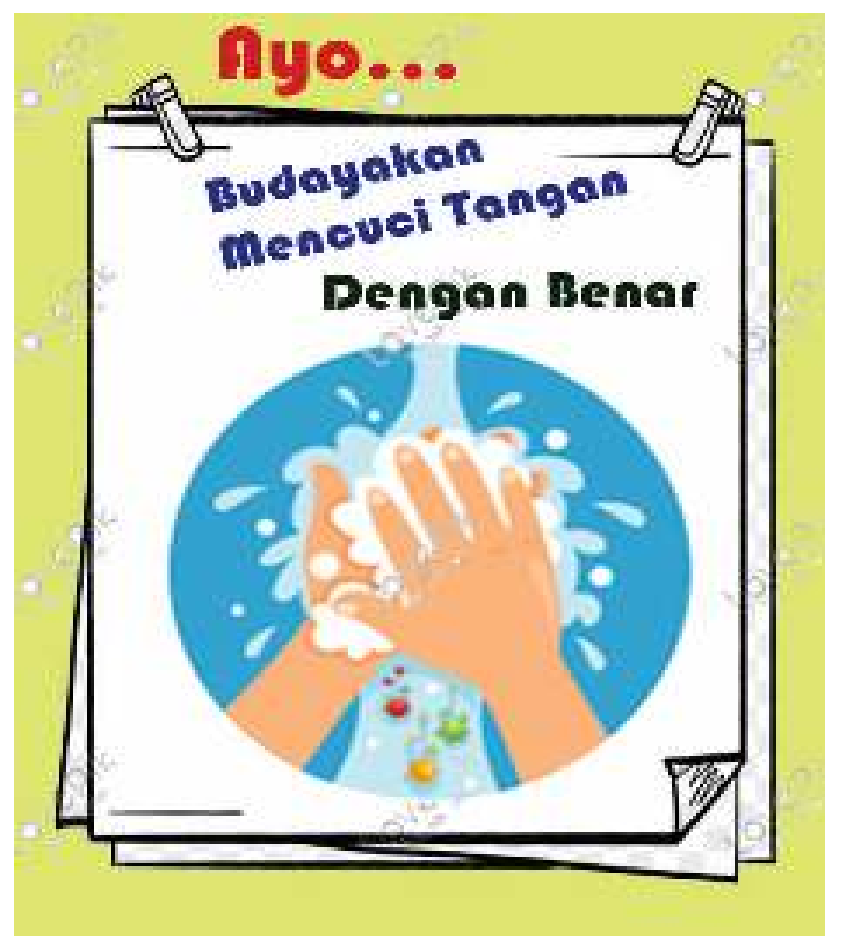

Gambar 3. Desain poster - 3 


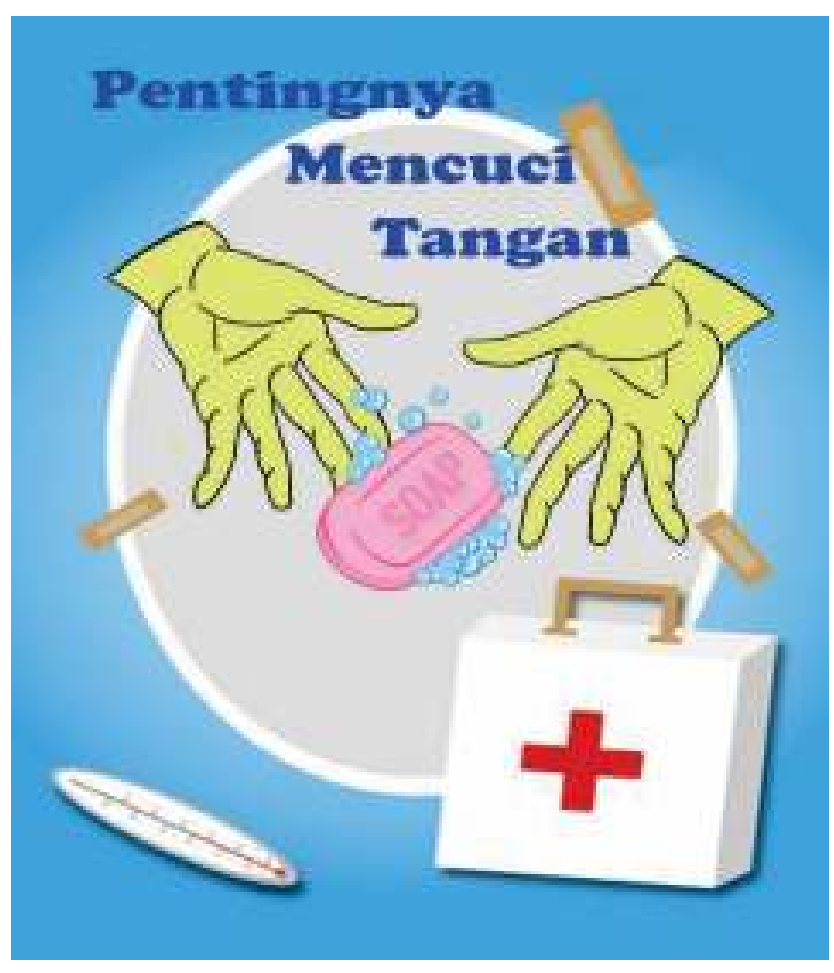

Gambar 4. Desain poster - 4

\section{d. Pengaplikasian Desain}

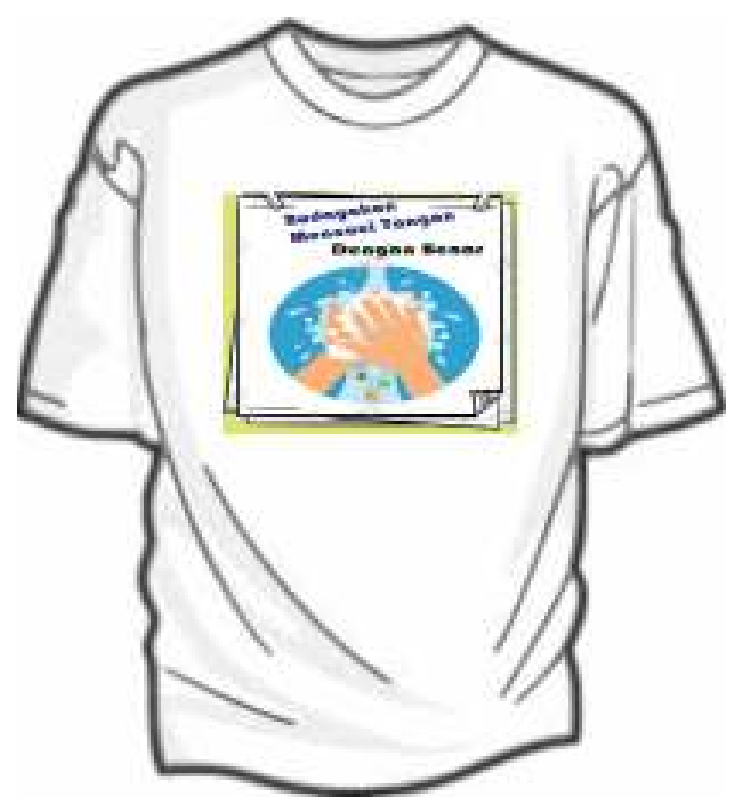

Gambar 5. Desain Kaos 


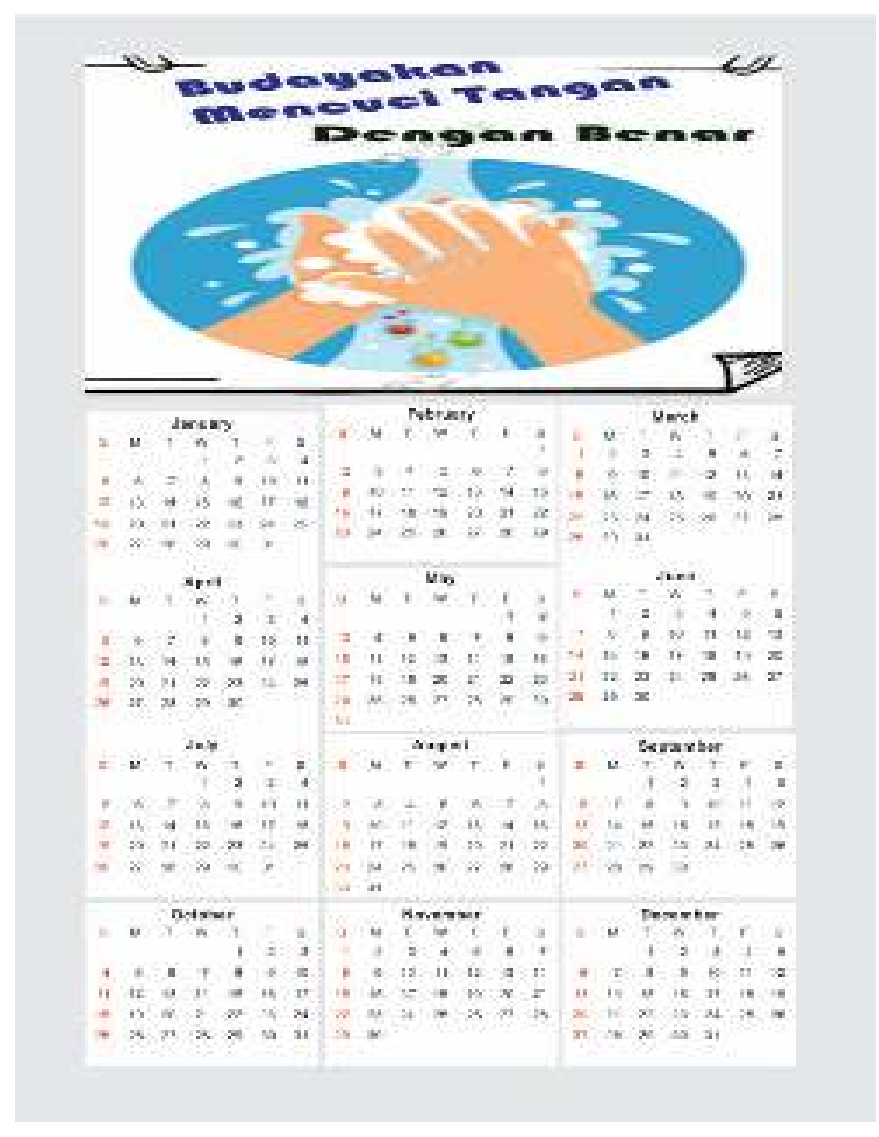

Gambar 6. Desain Kalender

\section{KESIMPULAN}

Tangan adalah salah satu penghantar utama masuknya kuman penyakit ke tubuh manusia. Mencuci tangan adalah kegiatan membersihkan bagian telapak, punggung tangan, jari dan kuku jari. Tujuannya agar bersih dari kotoran dan membunuh kuman penyebab penyakit dapat yang merugikan kesehatan.

Cuci tangan dengan sabun dapat menghambat masuknya kuman penyakit ke tubuh manusia melalui perantaraan tangan. Kuman penyakit seperti virus dan bakteri tidak dapat terlihat secara kasat mata sehingga sering diabaikan dan mudah masuk ke tubuh manusia.

Iklan layanan masyarakat ini semoga dapat membantu mengingatkan masyarakat untuk mencuci tangan sebelum melakukan aktivitas atau sesudah melakukan aktivitas menggunakan sabun, sehingga masyakat lebih sehat dengan membudayakan cuci tangan pakai sabun. 


\section{DAFTAR PUSTAKA}

[1] Asda Patria (2020). Perilaku Cuci Tangan Pakai Sabun (Ctps) Dan Kejadian Penyakit Infeksi Dalam Keluarga Di Wilayah Desa Donoharjo Kabupaten Sleman. Jurnal Media Keperawatan: Politeknik Kesehatan Makassar Vol. 11 No. 012020.

[2] Dahlan, A. K., \& Umrah. (2013). Ajaran Ketrampilan Dasar Praktik Kebidanan. Malang: Inti Media.

[3] Samsuridjal D. (2009). Raih kembali kesehatan. Jakarta: PT Kompas media nusantara.

[4] https:/halosehat.com/gaya-hidup/cara-hidup-sehat/cara-mencuci-tangan-yangbenar-dan-steril

[5] https://id.wikipedia.org/wiki/Iklan_layanan_masyarakat 